\title{
MATEMATIKA ISLAM? \\ STUDI KASUS PENGARUH MATAKULIAH MATEMATIKA ISLAM TERHADAP SIKAP MATEMATIS MAHASISWA TADRIS MATEMATIKA IAIN PEKALONGAN
}

\author{
${ }^{1)}$ Heni Lilia Dewi, ${ }^{2)}$ Awanda Widyastuti \\ Tadris Matematika, Fakultas Tarbiyah dan Ilmu Keguruan, Institut Agama Islam Negeri Pekalongan \\ ${ }^{1)}$ heni.lilia.dewi@iainpekalongan.ac.id
}

Received : 17/10/2019

Accepted : 28/01/2020

Published : 31/01/2020

\begin{abstract}
This study aims to determine how the implementatiom and influence of Islamic mathematics courses on students' mathematical attitudes. Islamic mathematics as an effort to strengthen mathematical literacy. The study was conducted on several fifth semester students who took Islamic mathematics courses as elective courses. The data analysis used quasiexperimental research with two experimental groups. Data obtained by doing observation, test and questionnaires to students. The result showed that there was a significant influence on Islamic mathematics courses on students' mathematical attitudes. This was indicated by the difference in mathematical attitudes between students who take and those who do not take Islamic mathematics courses.
\end{abstract}

Keywords: mathematical literacy, Islamic mathematics, mathematical attitudes.

\begin{abstract}
Abstrak
Penelitian ini bertujuan untuk mengetahui bagaimana penerapan dan pengaruh adanya matakuliah matematika islam terhadap sikap matematis mahasiswa. Matematika islam sebagai salah satu upaya penguatan literasi matematika. Penelitian dilakukan terhadap beberapa mahasiswa semester lima yang menempuh matakuliah matematika islam sebagai matakuliah pilihan. Analisis data menggunakan penelitian kuasi eksperimen dengan dua kelompok eksperimen. Data diperoleh dengan lakukan observasi dan pemberian angket kepada mahasiswa. Hasil penelitian menunjukkan bahwa ada pengaruh yang signifikan matakuliah matematika islam terhadap sikap matematis mahasiswa. Hal ini ditunjukkan dengan adanya perbedaan sikap matematis antara mahasiswa yang menempuh dengan yang tidak menempuh matakuliah matematika islam.
\end{abstract}

Kata Kunci: literasi matematika, matematika islam, sikap matematis.

\section{Pendahuluan}

Undang-undang Nomor 20 Tahun 2003 menyebutkan bahwa pendidikan memiliki tujuan untuk mengembangkan pembelajaran agar peserta didik secara aktif mengembangkan potensi dirinya untuk memiliki kekuatan spiritual keagamaan, pengendalian diri, kepribadian, kecerdasan, akhlak mulia, serta keterampilan yang diperlukan dirinya, masyarakat, bangsa dan negara. Pendidikan adalah salah satu hal yang fundamental dalam membentuk karakter siswa untuk menjadi pribadi yang unggul baik dari segi kognitif, afektif dan psikomotorik. 
Visi dan misi Fakultas Tarbiyah dan Ilmu Keguruan (FTIK) IAIN Pekalongan juga tidak melepaskan diri dari tujuan nasional tersebut. Salah satu misi FTIK IAIN Pekalongan yaitu menyelenggarakan pendidikan untuk menghasilkan lulusan Fakultas Tarbiyah dan Ilmu Keguruan yang memiliki kecerdasan spiritual, keluasan ilmu pengetahuan dan teknologi, kesetiaan terhadap keindonesiaan, kemandirian dan kepeloporan dalam kehidupan. Strategi untuk mencapai visi misi tersebut ditunjukkan adanya kurikulum KKNI di semua jurusan, termasuk jurusan Tadris Matematika.

Aspek kecerdasan spiritual juga menjadi hal yang sangat penting bagi seluruh mahasiswa jurusan di FTIK IAIN Pekalongan, termasuk jurusan Tadris Matematika. Dalam hal ini, sudah seharusnya mahasiswa jurusan Tadris Matematika memiliki sikap matematis yang tinggi. Pendapat lain mengungkapkan bahwa sikap matematis muncul atas dasar kognisi atau pengetahuan dan informasi tentang matematika, afeksi berkaitan dengan rasa senang dan tidak senang, konasi berkaitan dengan kecenderungan bertindak (Ruchaedi \& Baehaki, 2016). Sikap matematis dapat dilihat dari beberapa indikator yaitu: (1) adanya rasa senang dan ikhlas untuk mempelajari matematika, (2) sikap yang mendukung untuk mempelajari matematika, (3) pengetahuan yang cukup untuk mempelajari matematika, (4) rasa ingin tahu, (5) kemauan untuk bertanya, (6) kemampuan untuk memperoleh keterampilan dan pengalaman matematis (Nasrullah \& Marsigit, 2016).

Namun, berdasarkan observasi dan pengalaman peneliti, sikap matematis beberapa mahasiswa jurusan Tadris Matematika masih belum optimal. Hal ini ditunjukkan oleh kurang adanya rasa senang dan ikhlas, mahasiswa masih mengeluh jika diberikan tugas-tugas matematika. Mahasiswa juga kurang menunjukkan kemauan untuk bertanya dan pengalaman matematis. Faktor yang mendukung diantaranya adalah mahasiswa kurang mengerti apa peran dan manfaat materi matematika dalam kehidupan sehari-hari. Apalagi dengan status institut sebagai Perguruan Tinggi Keagamaan Islam Negeri (PTKIN), mahasiswa kurang dapat merasakan kebermanfaatan materi matematika terhadap Islam.

Kebutuhan ini sebenarnya sudah disalurkan oleh jurusan Tadris Matematika dengan menyusun Kurikulum KKNI yang salah satunya adalah penawaran matakuliah Matematika Islam. Menurut pendapat lainnya ilmu matematika berkaitan erat dengan tradisi spiritual umat Islam dan juga akrab dengan Al-Quran (Huda \& Mutia, 2017). Selain itu, di dalam ayat-ayat Al-Quran banyak ditemukan ayat yang menjelaskan tentang konsep matematika seperti tentang himpunan, barisan, bilangan cacah, bilangan bulat, dan lingkaranMatakuliah ini sebagai pendukung dalam literasi matematika, yaitu menganalisis dan menerapkan matematika dalam situasi dan kondisi kehidupan, salah satunya berkaitan dengan Islam. Pendapat lain yang sejalan yaitu bahwa pengintegrasian konsep matematika dengan nilai-nilai 
keislaman sangat penting diterapkan sebagai cara untuk mewujudkan karakter peserta didik (Maarif, 2015). Matakuliah ini berkaitan erat dengan terwujudnya literasi matematika, yaitu agar dapat menganalisis dan menerapkan matematika dalam situasi dan kondisi nyata, salah satunya yaitu berkaitan dengan Islam.

Matakuliah ini mempelajari tentang integrasi Matematika dan Islam. Namun demikian, sampai sekarang matakuliah Matematika Islam masih sebagai matakuliah pilihan, bukan matakuliah wajib. Padahal, jika mahasiswa dapat menerima materi matakuliah ini dengan baik, maka mereka akan memahami manfaat matematika untuk Islam. Dengan demikian, mahasiswa akan memiliki rasa senang dan ikhlas dalam belajar matematika, sehingga sikap matematis mahasiswa akan meningkat pula.

Berdasarkan kondisi dan kebutuhan tersebut, maka dilakukan penelitian studi kasus yang akan menganalisis Pengaruh Matakuliah Matematika Islam terhadap Sikap Matematis Mahasiswa Tadris Matematika IAIN Pekalongan.

\section{Metode Penelitian}

a. Jenis dan Pendekatan Penelitian;

Penelitian ini merupakan penelitian kuasi eksperimen dengan pendekatan penelitian kuantitatif. Penelitian eksperimen ini dilakukan untuk memberikan perlakuan berupa internalisasi aplikasi IBM SPSS terhadap sampel sehingga berpengaruh terhadap keterampilan mengolah data statistika mahasiswa. Desain penelitian yang digunakan adalah Quasi Eksperimental Design tipe Posttest Only Design. Penelitian merupakan eksperimen semu dikarenakan peneliti tidak dapat melakukan randomisasi subjek penelitian sesuai dengan ketentuan perguruan tinggi. Desain penelitian secara eksplisit dapat dilihat pada gambar berikut.

Ada dua kelompok eksperimen yaitu satu kelas yang memperoleh matakuliah Matematika Islam dan satu kelas lainnya yang memperoleh matakuliah Matematika Islam

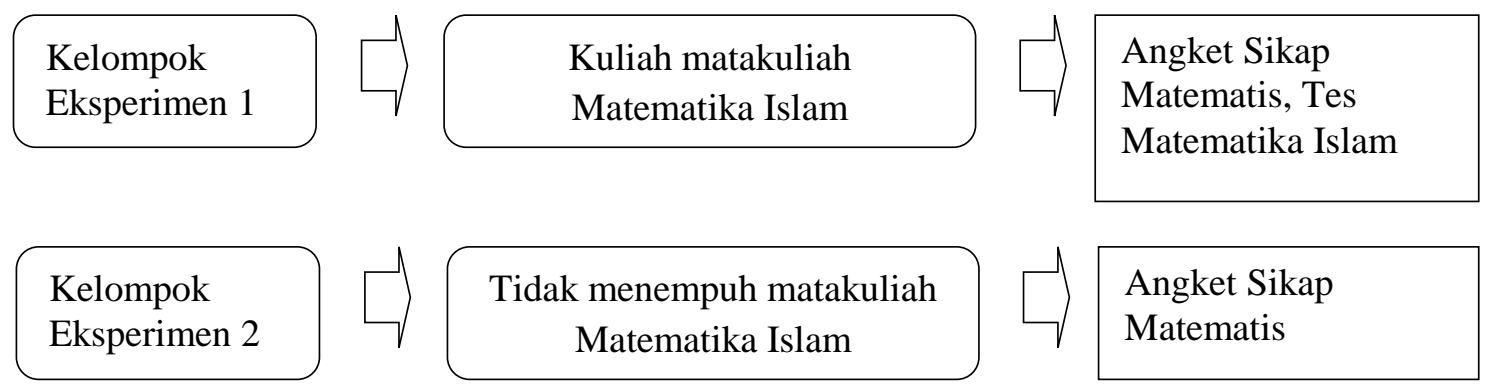

Gambar 1. Metode Penelitian

b. Lokasi dan Subjek Penelitian 
Penelitian ini dilaksanakan di Fakultas Tarbiyah dan Ilmu Keguruan IAIN Pekalongan jurusan Matematika yang berlokasi di Jalan Pahlawan KM 05 Rowolaku Kecamatan Kajen Kabupaten Pekalongan. Populasi pada penelitian adalah mahasiswa Jurusan Tadris Matematika Fakultas Tarbiyah dan Ilmu Keguruan IAIN Pekalongan. Teknik sampling yang digunakan adalah cluster random sampling.

c. Prosedur dan tahapan penelitian

1) Penelitian dan studi pendahuluan yang terdiri dari observasi lapangan dan perencanaan penggalian data

2) Pelaksanaan penelitian melalui wawancara dan observasi secara langsung

3) Melakukan penyusunan instrumen

4) Menentukan kelompok eksperimen 1 yaitu kelas yang menempuh matakuliah Matematika Islam dan kelompok eksperimen 2 yaitu kelas yang tidak menempuh matakuliah matematika Islam.

5) Memberikan tes berupa tes sikap matematis mahasiswa.

6) Pelaporan hasil penelitian dan saran terhadap lembaga.

d. Teknik Pengumpulan Data;

Adapun teknik pengumpulan dan analisis data yang dilakukan dalam penelitian ini dapat dijelaskan sebagai berikut:

1) Observasi, melihat secara langsung perkuliahan Matematika Islam.

2) Tes, digunakan untuk mendapatkan data nilai matakuliah Matematika Islam.

3) Angket, digunakan untuk mendapatkan data sikap matematis mahasiswa.

4) Dokumentasi, digunakan untuk mendokumentasikan seluruh kegiatan penelitian

e. Metode Analisis Data;

1) Statistik Deskriptif

Data yang diperoleh yaitu deskripsi nilai matakuliah Matematika Islam dan skor sikap matematis. Data akan disajikan dalam bentuk data deskriptif yang terdiri atas skor rata-rata (mean), standar deviasi, varian, skor maksimum, dan skor minimum.

2) Uji Persyaratan Analisis Data

Uji persyaratan yang dilaksanakan dalam penelitian yaitu normalitas dan homogenitas. Uji normalitas dilakukan untuk menguji distribusi sebaran data dari variabel penelitian yang diteliti. Uji normalitas multivariat dilakukan dengan membuat scatter-plot antara jarak mahalanobis dengan chi-square. Jika scatter-plot cenderung membentuk garis lurus dan lebih dari 50\% nilai jarak mahalanobis kurang dari atau sama dengan chi-square, maka data berdistribusi normal. Selain itu, kenormalan data juga dapat dilihat dari koefisien korelasi antara jarak mahalanobis dengan nilai chi-square. Jika nilai $r$ lebih dari nilai $r$ tabel, maka 
data berdistibrusi normal. Sedangkan uji homogenitas dan penarikan suatu kesimpulan dilakukan pada taraf signifikansi $\alpha=0,05$. Dalam hal ini, kriteria keputusannya adalah jika nilai signifikansi lebih dari 0,05 maka dapat disimpulkan bahwa matriks varians kovarians homogen. Berdasarkan hasil analisis, diperoleh hasil bahwa data angket sikap matematis mahasiswa berdistrubusi normal dan homogen.

3) Uji Keefektifan Perbedaan Kelompok Eksperimen 1 dan Eksperimen 2

Uji-t univariat digunakan untuk menguji apakah sikap matematis mahasiswa Kelompok eksperimen 1 lebih baik daripada Kelompok eksperimen 2. Secara umum, hipotesis yang akan diuji adalah sebagai berikut.

$$
\begin{gathered}
H_{0}: \mu_{1} \leq \mu_{2} \\
H_{0}: \mu_{1}>\mu_{2}
\end{gathered}
$$

Keterangan:

$\mu_{1}$ : rata-rata skor sikap matematis kelompok eksperimen 1 (kuliah Matematika Islam)

$\mu_{2}$ : rata-rata skor sikap matematis kelompok eksperimen 2 (tidak menempuh kuliah Matematika Islam)

Dengan taraf signifikan $\propto=0,05$. Statistik uji yang digunakan jika varians kedua sampel homogen adalah:

$$
t=\frac{\overline{x_{1}}-\overline{x_{2}}}{\sqrt{S^{2}\left(\frac{1}{n_{1}}+\frac{1}{n_{2}}\right)}}
$$

$\underset{\text { Dengan }}{ } S^{2}=\frac{\left(n_{1}-1\right) S_{1}{ }^{2}+\left(n_{2}-1\right) S_{2}{ }^{2}}{n_{1}+n_{2}-2}$, atau jika varians kedua sampel tidak homogen maka statistik yang digunakan adalah:

$$
t=\frac{\overline{x_{1}}-\overline{x_{2}}}{\sqrt{\frac{S_{1}^{2}}{n_{1}}+\frac{S_{2}^{2}}{n_{2}}-2 r\left(\frac{S_{1}}{n_{1}}+\frac{S_{2}}{n_{2}}\right)}}
$$

Keterangan:

$\bar{x}_{1}$ : nilai rata-rata skor sikap matematis kelompok eksperimen 1

$\overline{x_{2}}$

: nilai rata-rata skor sikap matematis kelompok eksperimen 2

$S_{1}^{2}$ : varians skor sikap matematis kelompok eksperimen 1

$S_{2}{ }^{2}$ : varians skor sikap matematis kelompok eksperimen 2

$\mathrm{r}$ : korelasi antara kedua sampel

$\mathrm{n}_{1}$ : banyaknya mahasiswa kelompok eksperimen 1 
$\mathrm{n}_{2}$ : banyaknya mahasiswa kelompok eksperimen 2

Kriteria keputusan yaitu $\mathrm{H}_{0}$ ditolak jika $t_{\text {hitung }}>\mathrm{t}_{\left(\alpha, \mathrm{n}_{1}+\mathrm{n}_{2}-2\right)}$. Pengujian hipotesis perbandingan dalam penelitian ini menggunakan bantuan SPSS dengan kriteria keputusan tolak $\mathrm{H}_{0}$ jika nilai signifikansinya kurang dari 0,05 .

4) Uji Pengaruh Matakuliah Matematika Islam terhadap Sikap Matematis Mahasiswa

Uji regresi digunakan untuk mengetahui apakah ada pengaruh matakuliah Matematika Islam terhadap Sikap Matematis Mahasiswa. Langkah penelitiannya adalah sebagai berikut.

a) Menentukan Hipotesis

Ho: tidak ada pengaruh secara signifikan antara matakuliah Matematika Islam terhadap sikap matematis mahasiswa

Hi: ada pengaruh secara signifikan antara matakuliah Matematika Islam terhadap sikap matematis mahasiswa

b) Menentukan Persamaan Regresi

Persamaan regresinya adalah sebagai berikut.

$\hat{Y}=a+b X$

Dengan:

$\hat{Y}$ : skor sikap matematis mahasiswa

$X$ : nilai matakuliah Matematika Islam

$a:$ konstanta

$b$ : koefisien regresi (nilai peningkatan ataupun penurunan)

c) Uji-t

Uji-t dilakukan untuk mengetahui apakah ada pengaruh yang signifikan antara matakuliah Matematika Islam terhadap sikap matematis mahasiswa, yaitu dengan membandingkan nilai $t$ hitung dengan $t$ Tabel distribusi t dicari pada $\alpha=5 \%$.

\section{Hasil dan Pembahasan}

Hasil penelitian berdasarkan uji perbedaan rata-rata menunjukkan bahwa ada perbedaan sikap matematis yang signifikan antara kelas yang menempuh matakuliah Matematika Islam dengan kelas yang tidak menempuh matakuliah Matematika Islam. Hal ini ditunjukkan oleh hasil analisis SPSS yaitu nilai t hitung sebesar 4,057 dan nilai Sig. (2-tailed) sebesar 0,000. Hasil ini juga diperkuat oleh perbedaan rata-rata sikap matematis yaitu 78,03 untuk kelas yang menempuh Matematika Islam dan 66,39 untuk kelas yang tidak menempuh Matematika Islam. Analisis tersebut menunjukkan bahwa sikap matematis mahasiswa yang menempuh matakuliah Matematika Islam lebih baik daripada bahwa sikap matematis mahasiswa yang tidak menempuh matakuliah Matematika Islam. 
Mahasiswa yang menempuh matakuliah Matematika Islam memiliki sikap matematis yang lebih tinggi. Adanya matakuliah Matematika Islam ini merupakan salah satu matakuliah pilihan yang diajukan oleh kurikulum KKNI jurusan Tadris Matematika IAIN Pekalongan. Matakuliah ini ditempuh oleh mahasiswa semester V. Hal ini sejalan dengan pendapat yang menegaskan bahwa dukungan dari struktur atau kurikulum sekolah sangat mempengaruhi sikap matematis siswa (Farooq \& Shah, 2008). Dalam hal ini, kurikulum di perguruan tinggi keislaman negeri adalah kurikulum KKNI pada tiap jurusan termasuk jurusan Tadris Matematika.

Hasil penelitian yang berikutnya berdasarkan hasil analisis regresi menunjukkan bahwa nilai matakuliah Matematika Islam berpengaruh terhadap sikap matematis mahasiswa. Hasil ini diperkuat oleh pendapat yang mengungkapkan bahwa anak yang mahir bermatematika memiliki beberapa potensi yaitu menguasai konsep matematika penalaran yang logis dan positive disposition yaitu sikap bahwa matematika bermanfaat bagi kehidupannya . Manfaatnya diantaranya yaitu berkaitan dengan Islam. Uji regresi ditunjukkan oleh persamaan:

$\mathrm{Y}=16,672+0,820 \mathrm{X}$, dimana $\mathrm{Y}$ menyatakan sikap matematis dan $\mathrm{X}$ menyatakan nilai matakuliah Matematika Islam.

Persamaan ini dapat digunakan untuk memprediksi atau mengestimasi sikap matematis mahasiswa ditinjau dari nilai matakuliah Matematika Islam. Matematika Islam merupakan matakuliah yang berisi integrasi nilai-nilai matematika dengan Islam. Karena pada hakikatnya secara aksiologi, setiap ilmu yang dipelajari oleh manusia pasti aka nada manfaatnya (Yuliana, 2017). Salah satunya yaitu manfaat matematika bagi Islam. Pendapat lain yang sejalan yaitu bahwa pengintegrasian konsep matematika dengan nilai-nilai keislaman sangat penting diterapkan sebagai cara untuk mewujudkan karakter peserta didik (Maarif, 2015).

Matematika sangat berkaitan dengan beberapa cabang ilmu agama, misalnya Fikih. Hal ini juga diperkuat oleh pendapat bahwa dalam hal tertentu, matematika memiliki kesamaan karakteristik dengan ilmu fikih, yakni sama-sama berpedoman pada aturan, hukum yang jelas, rumus, dan bertumpu pada kesepakatan sehingga dapat diformulasi rumus secara matematis (Muniri, 2016). Beberapa penerapan atau integrasi Matematika Islam, sekaligus materi yang diajarkan dalam kuliah Matematika Islam diantaranya adalah sebagai berikut.

a. Memahami Keesaan Allah dengan menggunakan Konsep Limit

Jika diperhatikan, barisan bilangan asli 1, 2, 3, .., n disebut barisan tak hingga. Tidak ada yang tahu berapa bilangan n karena hanya Allah SWT yang tahu. Konsep kehidupan ini tidak lain adalah keabadian dan kekekalan yang dimiliki oleh Allah. 
b. Memahami Sikap Berserah Diri dengan Konsep Pecahan.

Pecahan $=0$ jika dipahami 1 sebagai Allah SWT pemberi rezeki dan kehidupan manusia, sedangkan tak hingga adalah sifat sombong manusia yang tidak pernah berpuas diri, maka hasilnya adalah nol yaitu manusia tidak akan mendapat ridho dari Allah SWT.

c. Memahami Kejujuran dengan Konsep Perkalian

$+\mathrm{x}+=+$; positif dikalikan positif maka hasilnya negatif, dapat diartikan jika kebenaran dikatakan benar maka termasuk golongan orang benar.

$+\mathrm{x}-=-$; positif dikalikan negatif hasilnya negatif, dapat diartikan jika kebenaran dikatakan sebagai sesuatu yang salah maka termasuk golongan orang salah, dan juga sebaliknya.

- x - = -; negatif dikalikan negatif hasilnya positif, dapat diartikan sesuatu yang salah dikatakan salah maja termasuk golongan orang benar.

\section{Kesimpulan}

Implementasi matakuliah Matematika Islam meliputi penerapan dan kaitan antara matematika dengan Islam. Mahasiswa yang menempuh matakuliah Matematika Islam menunjukkan sikap matematis yang lebih baik daripada mahasiswa yang tidak menempuh matakuliah Matematika Islam. Oleh karena itu, matakuliah ini perlu diberikan tidak hanya sebagai matakuliah pilihan, tetapi sebagai matakuliah wajib, terutama pada perguruan tinggi keagaman negeri (PTKIN), karena matakuliah Matematika Islam mempengaruhi sikap matematis mahasiswa. Hasil penelitian ini juga dapat memberikan rujukan dan masukan kepada perguruan tinggi lain yang kurikulumnya belum menawarkan matakuliah Matematika Islam, melihat akan pentingnya matakuliah Matematika Islam ditinjau dari sikap matematis mahasiswa.

\section{Ucapan Terimakasih}

Penulis mengucapkan terimakasih kepada dosen jurusan Tadris Matematika, khususnya yang mengampu matakuliah Matematika Islam. Ucapan terimakasih juga disampaikan kepada seluruh mahasiswa semester V jurusan Tadris Matematika dan seluruh pihak yang mendukung penelitian ini.

\section{Pustaka}

Farooq, M., \& Shah, S. (2008). Students' Attitude Towards Mathematics. Pakistan Economic and Social Review, 46(1), 75-83.

Huda, M., \& Mutia, M. (2017). Mengenal Matematika dalam Perspektif Islam. FOKUS Jurnal Kajian Keislaman Dan Kemasyarakatan, 2(2), 182. https://doi.org/10.29240/jf.v2i2.310 
Maarif, S. (2015). Integrasi Matematika Dan Islam. Jurnal Ilmiah Studi STKIP Siliwangi Bandung, 4(2), 223-236. https://doi.org/10.24090/insania.v19i2.716

Muniri, M. (2016). Kontribusi Matematika dalam Konteks Fikih. Ta'allum: Jurnal Pendidikan Islam, 4(2), 193-214. https://doi.org/10.21274/taalum.2016.4.2.193-214

Nasrullah, A., \& Marsigit. (2016). Keefektifan Problem Posing dan Problem Solving Ditinjau dari Ketercapaian The Effectiveness of Problem Posing and Problem Solving in Terms of Basic Competence Attainment, Mathematical Method, and Mathematical Attitude. PHYTAGORAS: Jurnal Pendidikan Matematika, 11(2), 123-135. https://doi.org/10.21831/pg.v11i2.11180

Ruchaedi, D., \& Baehaki, I. (2016). Pengaruh Problem Based Learning (Pbl) Terhadap Kemampuan Heuristik Pemecahan Masalah Dan Sikap Matematis Siswa Sekolah Dasar. Jurnal Cakrawala Pendas, 2(2), 20-32. https://doi.org/10.31949/jcp.v2i2.331

Yuliana, P. (2017). Peningkatan Kemampuan Pemahaman Konsep dan Sikap Matematis Menggunakan Model Scientific dalam Pendekatan Tematik Integratif di Kelas IV SD. Wahana Didaktika, 15(2), 99-110. 
